\title{
KUALITAS HIDUP PASIEN GAGAL GINJAL KRONIS DENGAN TERAPI HEMODIALISA
}

\section{[QUALITY OF LIFE OF PATIENTS WITH CHRONIC KIDNEY DISEASE WHO UNDERGO HEMODIALYSIS THERAPY]}

\author{
Nolla Lisa Lolowang, Welmin M.E Lumi, Amelia A. Rattoe \\ Akademi Keperawatan Bethesda Tomohon \\ e-mail : lisanolla@yahoo.co.id \\ DOI : 10.47718/jpd.v8i01.1183
}

\section{ABSTRAK}

\section{ABSTRACT}

\begin{abstract}
Latar Belakang: Gagal ginjal kronis merupakan penyakit yang berkepanjangan, sangat berbahaya, asimptomatik sejak tahap awalnya. Perlu untuk mengetahui dan mengevaluasi kualitas hidup pasien gagal ginjal kronis yang menjalani terapi hemodialisa sehingga dapat memberikan masukan kepada perawat dalam menetapkan intervensi terapeutik dalam membangun hubungan, memberikan dukungan secara komprehensif kepada pasien dan keluarga. Tujuan: Penelitian ini bertujuan memberikan gambaran kualitas hidup pasien gagal ginjal kronis dengan terapi hemodialisa. Metode: Desain penelitian yang digunakan adalah desain deskriptif. Jumlah sampel sebanyak 45 orang. Metode sampling yang digunakan adalah total sampling. Instrumen penelitian yang digunakan adalah kuesioner WHOQOL-BREF. Hasil: Hasil penelitian menunjukkan 17 orang (37.8\%) memiliki kualitas hidup buruk pada domain kesehatan fisik, 6 orang (13.3\%) memiliki kualitas hidup buruk pada domain psikologis, 14 orang (31.1\%) memiliki kualitas hidup buruk pada domain hubungan sosial dan 6 orang (13.3) memiliki kualitas hidup yang buruk pada domain lingkungan. Kesimpulan: kualitas hidup pasien gagal ginjal kronis dengan terapi hemodialisa bervariasi antara baik dan buruk, sehingga perlu peran perawat untuk memberikan edukasi, dukungan dan motivasi.
\end{abstract}

Kata Kunci: Kualitas hidup, hemodialisa, gagal ginjal kronis

Introduction: Chronic kidney disease is a prolonged, very dangerous, asymptomatic disease from its early stages. It is necessary to know and explain the quality of life of patients with chronic kidney disease who undergo hemodialysis therapy so that they can give advice to nurses in determining therapeutic interventions in building relationships, providing comprehensive support to patients and their families. Aim: The aim of this study was to offer an overview of the quality of life of patients with chronic kidney disease who undergo hemodialysis therapy. Method: Desain of this research was descriptive desain. Total samples were 45 patients. Sampling method was total sampling. The instruments which used in this research were WHOQOL-BREF. Results: The results showed 17 people (37.8\%) had a poor quality of life in the 
health domain, 6 people (13.3\%) had a poor quality of life in the psychological domain, 14 people (31.1\%) had a poor quality of life in the social relationship domain and 6 people (13.3) had quality bad life in the environmental domain. Conclution: The quality of life of patients with chronic kidney disease who undergo hemodialysis therapy varied between good and bad so the role of nurses in providing education, support, and motivation is needed.

Key words: quality of life, hemodialysis, chronic kidney disease.

\section{PENDAHULUAN}

\section{Penyakit gagal ginjal kronis didefinisikan dengan perkiraan laju}

filtrasi glomerulus 15 sampai $59 \mathrm{~mL} /$ menit/1.73 $\mathrm{m}^{2}$. yang dikalibrasi dengan pehitungan kreatinin serum. Penyakit gagal ginjal kronis ditandai dengan penurunan fungsi ginjal yang progresif dan ireversibel, sebagai akibat dari berbagai penyebab dan berbagai faktor yang mengakibatkan perubahan struktur dan fungional ginjal tersebut. Gagal ginjal kronis merupakan penyakit yang berkepanjangan, sangat berbahaya, asimptomatik sejak tahap awalnya (Murphy, et al, 2016).

Berdasarkan berbagai data epidemiologi, penyakit gagal ginjal kronis memengaruhi rata-rata $10 \%$ populasi di seluruh dunia. Hal ini terjadi karena peningkatan populasi dan peningkatan penyakit seperti diabetes mellitus, hipertensi dan obesitas (Dąbrowska-Bender, 2018). Indonesian Renal Registry (IRR) mencatat tahun 2015 terdapat 30.554 pasien aktif yang menjalani dialysis, yang sebagian besarnya adalah pasien gagal ginjal kronis (Kementrian Kesehatan RI, 2018).

Perawatan konservatif atau dialisis adalah salah satu tindakan yang harus diimplementasikan segera setelah pasien didiagnosis gagal ginjal kronis; jika tidak, maka akan terjadi komplikasi yang dapat menyebabkan kematian. Hemodialisis adalah pengobatan yang paling sering digunakan, merupakan pengobatan seumur hidup atau berlanjut 
sampai pasien mendapatkan transplantasi ginjal (Gesualdo, et al, 2017). Hemodialisis adalah teknik pembersihan darah ekstrakorporeal yang digunakan untuk menghilangkan produk sisa metabolisme yang terakumulasi pada pasien dengan penyakit ginjal stadium akhir. Zat terlarut dan cairan dibersihkan melalui membrane semipermeable dengan pemisahan massa yang berbeda melalui mekanisme difusi, konveksi dan adsorpsi (Ronco \& Clark, 2018).

Menurut World Health Organization (WHO), kualitas hidup adalah persepsi individu tentang hidupnya dalam konteks budaya dan sistem nilai dimana mereka hidup dan dalam kaitannya dengan tujuan, harapan, standar, dan masalah. Kualitas hidup merupakan perbandingan antara harapan dan kenyataan. Pada pasien gagal ginjal kronis, kualitas hidup juga mencerminkan kualitas pengobatan karena melibatkan proses fisik, psikologis, dan sosial yang ingin dicapai. Pengumpulan data kualitas hidup pasien gagal ginjal kronis akan membantu pasien memahami penyakit mereka dan merupakan implikasi dari pengobatan (Tannor, et al, 2019).

Kehidupan pasien dengan penyakit gagal ginjal kronis diatur dan disesuaikan dengan perubahan yang disebabkan oleh sifat penyakit dan metode pengobatannya. Terlebih lagi, pasien bergantung pada alat dialisis dan tenaga medis. Perawatan juga melibatkan pembatasan cara makan dan minum serta aktivitas fisik. Gejala mental dan fisik sangat memengaruhi tingkat kualitas hidup yang dirasakan oleh pasien. Pada saat bersamaan, pasien harus merasakan dampak negatif terapi dialisis seperti nyeri, gangguan tidur, depresi, melemahnya fluktuasi tekanan darah, dan nyeri perut sehingga mengurangi kualitas hidup (Dąbrowska- 
Bender, 2018).

Penyakit gagal ginjal kronis ini menyebabkan serangkaian perubahan, pembatasan dan adaptasi pada aktivitas sehari-hari dan interaksi sosial. Oleh karena itu perlu untuk mengetahui dan mengevaluasi kualitas hidup pasien gagal ginjal kronis yang menjalani terapi hemodialisa. Analisis ini akan memberikan masukan kepada perawat dalam menetapkan intervensi terapeutik dalam membangun hubungan, memberikan dukungan secara komprehensif kepada pasien dan keluarga.

Tujuan penelitian ini adalah memberikan gambaran kualitas hidup pasien gagal ginjal kronis dengan terapi hemodialisa.

Desain penelitian ini adalah deskriptif, dilaksanakan pada September, 2020 di instalasi hemodialisa salah satu rumah sakit swasta di Kota Tomohon. Metode sampling menggunakan total sampling dengan jumlah responden 45 orang. Kriteria inklusi adalah pasien yang didiagnosis gagal ginjal kronis, menjalani terapi hemodialisa minimal 1 bulan. Kriteria ekslusi adalah pasien dengan penurunan kesadaran, memiliki keterbatasan dalam berkomunikasi, membaca dan menulis.

Kuesioner dibagikan di ruang hemodialisa, dan rata-rata pasien menjawab kurang lebih 15 menit. Kuesioner sosiodemografi berisi umur, jenis kelamin dan lama menjalani terapi hemodialisa. Kualitas hidup diukur dengan kuesioner The World Health Oganization Quality of Life, dengan 26 item pernyataan yang mengukur 4 domain yaitu domain kesehatan fisik, domain psikologis, domain hubungan sosial dan domain lingkungan (Joshi, et al, 2017). Kuesioner ini diadaptasi ke bahasa Indonesia oleh tim gabungan Kementerian Kesehatan, Universitas 


\section{HASIL DAN}

\section{PEMBAHASAN}

Atmajaya Jakarta, dan RS Fatmawati Jakarta. Uji validitas dan reliabilitas telah dilakukan dan hasilnya kuesioner WHOQOL-BREF ini merupakan instrument yang valid dan reliable untuk mengukur kualitas hidup pasien gagal ginjal kronis yang menjalani terapi hemodialisa. Total skor dari jawaban responden dianalisis secara univariat untuk mencari frekuensi dan persentasi menggunakan software statistik.

Tabel 1 Gambaran karakteristik pasien gagal ginjal kronis yang menjalani terapi hemodialisa menurut umur, jenis kelamin, dan lama menjalani hemodialisa $(n=45)$

\begin{tabular}{|c|c|c|}
\hline Variabel & Frekuensi & Persentase \\
\hline \multicolumn{3}{|l|}{ Umur } \\
\hline $17-25$ & 2 & 4.4 \\
\hline $26-45$ & 5 & 11.1 \\
\hline $46-65$ & 28 & 62.2 \\
\hline$>65$ & 10 & 22.2 \\
\hline \multicolumn{3}{|l|}{ Jenis kelamin } \\
\hline Laki-laki & 28 & 62.2 \\
\hline Perempuan & 17 & 37.8 \\
\hline \multicolumn{3}{|l|}{ Lama HD } \\
\hline$\leq 12$ bulan & 19 & 42.2 \\
\hline $13-24$ bulan & 11 & 24.4 \\
\hline >24 bulan & 15 & 33.3 \\
\hline
\end{tabular}

Pada tabel 1 dapat dilihat bahwa mayoritas pasien berumur 46-65 tahun sebanyak 28 orang (62.2\%), mayoritas pasien berjenis kelamin laki-laki sebanyak 28 orang (62.2\%) dengan mayoritas lama HD $<12$ bulan sebanyak 19 orang (42.2\%). 
Tabel 2 Gambaran kualitas hidup pasien gagal ginjal kronis dengan terapi hemodialisa di RSU GMIM Bethesda Tomohon ( $n=45)$

\begin{tabular}{lcc}
\hline \multicolumn{1}{c}{ Variabel } & Frekuensi & Persentase \\
\hline Domain kesehatan fisik & \multicolumn{2}{l}{} \\
\hline Buruk & 17 & 37.8 \\
\hline Baik & 28 & 62.2 \\
\hline Domain psikologis & 6 & 13.3 \\
\hline Buruk & 39 & 86.7 \\
\hline Baik & \multicolumn{2}{l}{31.1} \\
\hline Domain hubungan sosial & 14 & 68.9 \\
\hline Buruk & 31 & 13.3 \\
\hline Baik & \multicolumn{3}{c}{86.7} \\
\hline Domain lingkungan & 6 & memiliki
\end{tabular}

kualitas hidup buruk pada domain kesehatan, 6 orang (13.3\%) memiliki

kualitas hidup buruk pada domain psikologis, 14 orang (31.1\%)

memiliki kualitas hidup buruk pada domain hubungan sosial dan 6

orang (13.3) memiliki kualitas hidup yang buruk pada domain

lingkungan.

Tabel 3 Perbedaan domain kualitas hidup; mean dan standar deviasi berdasarkan karakteristik pasien $(n=45)$

\begin{tabular}{ccllr}
\hline Variabel & Kesehatan Fisik & Psikologis & Hubungan sosial & Lin \\
\hline Jenis kelamin & & & & \\
\hline Laki-laki & $21.57 \pm 5.41$ & $19.96 \pm 4.48$ & $9.64 \pm 2.55$ & $27 \pm 6$ \\
\hline Perempuan & $23.06 \pm 2.33$ & $22.76 \pm 2.68$ & $11.12 \pm 1.65$ & 29.71 \\
\hline Lama HD & & & \\
\hline$\leq 12$ bulan & $22.65 \pm 3.51$ & $21.88 \pm 2.69$ & $10.76 \pm 1.75$ & $30 \pm 4$ \\
\hline $13-24$ bulan & $20.54 \pm 7.09$ & $19.38 \pm 6.33$ & $9.38 \pm 3.61$ & 25.41 \\
\hline$>24$ bulan & $23.13 \pm 2.38$ & $21.47 \pm 2.58$ & $10.47 \pm 1.30$ & $28.5 \vdots$ \\
\hline Umur & & & $28.5:$ \\
\hline $17-25$ & $21.5 \pm 6.36$ & $22 \pm 5.65$ & $11 \pm 1.41$ & $30.2:$ \\
\hline $26-45$ & $23.4 \pm 1.81$ & $22.6 \pm 2.60$ & $10.4 \pm 2.07$ & $28.6 \vdots$ \\
\hline $46-65$ & $23.29 \pm 3.23$ & $21.57 \pm 2.55$ & $10.64 \pm 1.54$ & $25.8:$
\end{tabular}


Pada usia produktif, sebagian besar orang mengabaikan pencegahan sebagai bentuk tindakan menghindari faktor resiko seperti merokok dan alcohol yang dapat meningkatkan kejadian penyakit hipertensi, serta pola hidup yang tidak sehat (Alfian, 2017). Pada usia 40 sampai 70 tahun, laju filtrasi glomelurus akan menurun secara progresif hingga $50 \%$ dari normal dimana terjadi penurunan kemampuan tubulus ginjal untuk mereabsorpsi dan pemekatan urin yang mengakibatkan penyakit diabetes mellitus pada usia produktif (Firmansyah, Fadraersada, \& Rusli, 2017)

Persentase laki-laki yang menderita CKD dengan hemodialisa lebih besar dari pada wanita, karena laki-laki lebih banyak yang mempunyai kebiasaan merokok, dimana perokok aktif berisiko 7 kali untuk menderita CKD bila dibandingkan dengan yang tidak merokok. Hal ini juga disebabkan karena pada perempuan terdapat hormone estrogen yang berfungsi untuk keseimbangan kadar kalsium sehingga dapat mencegah penyerapan oksalat yang mengakibatkan batu ginjal sebagai penyebab CKD (Theodora, Vehvilainen-Julkunen, \& SapountziKrepia, 2017).

Waktu perawatan sangat erat kaitannya dengan kualitas hidup. Lama didialisis menunjukkan perpanjangan hidup penderita yang secara langsung akan mengubah persepsi mereka tentang kualitas hidup mereka. Waktu perawatan berkontribusi untuk meningkatkan kualitas hidup ketika individu membandingkan status kesehatan mereka dari bulan ke bulan meskipun hemodialisis mengakibatkan keterbatasan fisik dan sosial. Pasien yang berpikir positif selama menjalani perawatan akan meringankan beban dan meningkatkan 
kualitas hidup (Marinho, et al, 2017).

Pasien dengan terapi hemodialisa akan mengalami gangguan aktivitas yang berdampak pada kesehatan fisik terutama mobilisasi sehingga perlunya perawatan berulang dalam jangka panjang akibat anemia, uremia, miopati, gangguan tulang dan mineral. Kebutuhan dasar terkait mobilisasi jika tidak terpenuhi akan menjadi salah satu faktor penyebab kematian. Keterbatasan aktivitas dapat mengakibatkan terjadinya stress, frustasi, depresi, penurunan daya ingat, mudah tersinggung dan sensitif (Sepadha, Sagala, \& Sagala, 2020). Aktivitas ringan seperti berjalan kaki merupakan hal yang sangat berguna karena menurunkan resiko obesitas, penyakit kardiovaskuler, dan diabetes mellitus. Penurunan aktivitas fisik pada pasien yang menjalani terapi hemodialisa disebabkan oleh pengaruh uremia pada fungsi otot yang menyebabkan atrofi, anemia, penyakit tulang, malnutrisi, dan kelelahan setelah menjalani hemodialisa. Menurut pasien, kelelahan dan suasana hati yang tertekan adalah salah satu hambatan utama untuk melakukan aktivitas fisik (Brys, et al 2020). Kelelahan merupakan hal yang kompleks yang terjadi secara persisten pada pasien yang menjalani hemodialisa (Leme, et al, 2020).

Terapi hemodialisa merupakan tindakan yang lama, mahal, dan sangat membutuhkan cairan dan diet. Penderita ginjal mengalami perasaan putus asa dan kecemasan tentang kondisi penyakit mereka serta tindakan perawatannya. Hal ini menyebabkan pasien mengalami harga diri rendah. Takut pada sesuatu yang tidak diketahui adalah reaksi umum pada penderita gagal ginjal kronis. Berbagai tes laboratorium yang rumit dan prosedur yang dilakukan, seperti 
ultrasound ginjal dan biopsi, pemasangan peritoneal kateter dialisis atau kateter vena sentral untuk hemodialisis, dan pembuatan vascular akses. Depresi, kecemasan dan gangguan mood, perubahan pola tidur, membuat pasien menarik diri bahkan ada yang berpikir untuk mengakhiri hidupnya (Theodora Kafkia, Vehvilainen-Julkunen, \& Sapountzi-Krepia, 2017). Depresi dikaitkan dengan peningkatan risiko kematian di antara pasien dengan gagal ginjal kronis (Rebollo Rubio, Morales Asencio, \& Eugenia Pons Raventos, 2017).

Dukungan sosial yang baik dapat meningkatkan kepuasan pasien mengenai perawatan dan kualitas hidup secara umum. Selain itu, dukungan sosial dapat meningkatkan kepatuhan menjalani managemen pengobatan. Di antara terapi modalitas dialisis, dukungan sosial terbukti mampu meningkatkan kualitas hidup pasien.Tingkat dukungan sosial yang lebih rendah meningkatkan risiko kematian dan mengurangi kepatuhan pengobatan (Da Silva, et al, 2016).

Agama dan spiritualitas dapat dianggap sebagai cara untuk memberikan makna pada kehidupan untuk memiliki harapan dan menerima kejadian yang tidak menyenangkan seperti penyakit kronis. Pasien dengan hemodialysis memiliki kualitas hidup yang baik ketika mereka menjadikan agama, spiritualitas dan keyakinan mereka menjadi sarana yang penting untuk mengatasi penyakitnya. Agama dan spiritualitas penting bagi pasien yang menjalani hemodialisis karena memengaruhi aspek penting kualitas hidup dan keterampilan koping seseorang (Lentsck, Marques, \& Kusumota, 2017). Selain agama dan spiritualitas, faktor pendapat juga mempengaruhi domain lingkungan pada kualitas hidup pasien dengan hemodialisa. Pasien dengan 


\section{KESIMPULAN}

\section{DAFTAR PUSTAKA}

pendapatan yang lebih tinggi dapat dengan mudah memilih perawatan yang sesuai dengan kebutuhan. Kecukupan finansial akan meningkatkan harga diri, kepuasan dan mengurangi kecemasan (Joshi, et al, 2017).

Penelitian ini mendapat izin dari pimpinan RSU GMIM Bethesda Tomohon sebagai lokasi penelitian dan sudah dilakukan uji etik di AKPER Bethesda Tomohon. Penelitian dilaksanakan dengan memperhatikan prinsip etika seperti menghormati harkat dan martabat manusia, menghormati privasi subjek penelitian, dan informed consent persetujuan menjadi responden.

$$
\text { Kualitas hidup pasien gagal ginjal kronis dengan terapi }
$$

hemodialisa bervariasi antara baik dan buruk, pada domain kesehatan, domain psikologis, domain hubungan sosial dan domain lingkungan. Peran perawat dalam memberikan edukasi, dukungan dan motivasi sangat diperlukan untuk meningkatkan kualitas hidup pasien gagal ginjal kronis yang menjalani terapi hemodialisa.

Alfians. (2017). Perbandingan Kualitas Hidup pasien Gagal Ginjal Kronik Diabetes meilitus dan hippertensi di ruangan hemodialisa. https://ejournal.unsrat.ac.id/index.php/jkp/article/view/16839

Brys, A. D. H. et al. (2020) 'Daily physical activity in patients on chronic haemodialysis and its relation with fatigue and depressive symptoms', International Urology and Nephrology. Springer Netherlands, 52(10), pp. 1959-1967. doi: 10.1007/s11255-02002578-9.

Dąbrowska-Bender, M. et al. (2018) 'The impact on quality of life of dialysis patients with renal insufficiency. Patient Preference and Adherence. Patient Preference and Adherence [revista en Internet] 2018 [acceso 11 julio 2020]; 12(1):577-583', Patient preference and adherence, 12, pp. 577-583. Available at: 
https://www.ncbi.nlm.nih.gov/pmc/articles/PMC5916456/pdf/p pa-12-577.pdf.

da Silva, S. M. et al. (2016) 'Suporte social de adultos e idosos renais crônicos em hemodiálise', Revista Latino-Americana de Enfermagem, 24. doi: 10.1590/1518-8345.0411.2752.

Firmansyah, F., Fadraersada, J., dan Rusli, R. (2017). Kajian Kualitas Hidup Pasien yang Menjalani Hemodialisa di RSUD. A.W. Sjahranie. Proceeding of Mulawarman Pharmaceuticals Conferences 201; 7, 51-56. https://doi.org/10.25026/mpc.v7i1.292

Gesualdo, G. D. et al. (2017) 'Factors Associated With the Quality of Life of Patients Undergoing Hemodialysis', Texto \& Contexto Enfermagem, 26(2), pp. 1-10. doi: 10.1590/010407072017005600015.

Joshi, U. et al. (2017) 'Assessment of quality of life in patients undergoing hemodialysis using WHOQOL-BREF questionnaire : a multicenter study', pp. 195-203.

Kementerian Kesehatan Republik Indonesia. (2018). Infodatin: Situasi penyakit ginjal kronis. Jakarta: Kementrian Kesehatan Republik Indonesia.

Leme, J. et al. (2020) 'Patient perception of vitality and measured physical activity in patients receiving haemodialysis', Nephrology, (June), pp. 1-7. doi: 10.1111/nep.13758.Lentsck MH, Marques S, Kusumota L. Spiritual well-being and quality of life of older adults in hemodialysis. 2017;70(4):689-96.

Marinho, C. L. A. et al. (2017) 'Quality of life of chronic renal patients undergoing hemodialysis', Revista da Rede de Enfermagem do Nordeste, 18(3), p. 396 . doi: 10.15253/21756783.2017000300016 .

Murphy, D. et al. (2016) 'Trends in prevalence of chronic kidney disease in the United States', Annals of Internal Medicine, 165(7), pp. 
473-481. doi: 10.7326/M16-0273.

Rebollo Rubio, A., Morales Asencio, J. M. and Eugenia Pons Raventos, M. (2017) 'Depression, anxiety and health-related quality of life amongst patients who are starting dialysis treatment', Journal of Renal Care, 43(2), pp. 73-82. doi: 10.1111/jorc.12195.

Ronco, C. and Clark, W. R. (2018) 'Haemodialysis membranes', Nature Reviews Nephrology. Springer US, 14(6), pp. 394-410. doi: 10.1038/s41581-018-0002-x.

Sepadha, D., Sagala, P., dan Sagala, W.G. (2020). Aktivitas Sehari-Hari Dan Kualitas Hidup Pasien Hemodialisa Di Rumah Sakit Umum Imelda. 2020;6(1).

Tannor, E. K. et al. (2019) 'Quality of life among patients with moderate to advanced chronic kidney disease in Ghana - A single centre study', BMC Nephrology. BMC Nephrology, 20(1), pp. 1-10. doi: 10.1186/s12882-019-1316-z.

Theodora Kafkia, R. N., Vehvilainen-Julkunen, K., \& Sapountzi-Krepia, D. (2017) 'Renal Patients ' Quality of Life as it is Affected by Pain', International Journal of Caring Sciences, 10(2), p. 1108. 